\title{
ENDOCRINE SIDE EFFECTS OF ANTI-CANCER DRUGS Effects of anti-cancer targeted therapies on lipid and glucose metabolism
}

\author{
Bruno Vergès, Thomas Walter ${ }^{1}$ and Bertrand Cariou ${ }^{2}$ \\ Service Endocrinologie, Diabétologie et Maladies Métaboliques, INSERM CRI 866, Hôpital du Bocage, CHU Dijon, \\ Université de Bourgogne, 21000 Dijon, France, 'Service d'Oncologie Digestive, Hospices Civils de Lyon, Hôpital \\ Edouard Herriot, 69437 Lyon Cedex 03, France and ${ }^{2}$ Clinique d'Endocrinologie, I'Institut du Thorax, INSERM UMR \\ 1087, CHU de Nantes, Nantes, France
}

Correspondence should be addressed to $B$ Vergès

Email bruno.verges@chu-dijon.fr

\begin{abstract}
During the past years, targeted therapies for cancer have been developed using drugs that have significant metabolic consequences. Among them, the mammalian target of rapamycin (mTOR) inhibitors and, to a much lesser extent, the tyrosine kinase inhibitors (TKIs) are involved. mTOR plays a key role in the regulation of cell growth as well as lipid and glucose metabolism. Treatment with mTOR inhibitors is associated with a significant increase in plasma triglycerides and LDL cholesterol. mTOR inhibitors seem to increase plasma triglycerides by reducing the activity of the lipoprotein lipase which is in charge of the catabolism of triglyceride-rich lipoproteins. The increase in LDL cholesterol observed with mTOR inhibitors seems to be due to a decrease in LDL catabolism secondary to a reduction of LDL receptor expression. In addition, treatment with mTOR inhibitors is associated with a high incidence of hyperglycemia, ranging from 13 to $50 \%$ in the clinical trials. The mechanisms responsible for hyperglycemia with new onset diabetes are not clear, but are likely due to the combination of impaired insulin secretion and insulin resistance. TKIs do not induce hyperlipidemia but alter glucose homeostasis. Treatment with TKIs may be associated either with hyperglycemia or hypoglycemia. The molecular mechanism by which TKIs control glucose homeostasis remains unknown. Owing to the metabolic consequences of these agents used as targeted anti-cancer therapies, a specific and personalized follow-up of blood glucose and lipids is recommended when using mTOR inhibitors and of blood glucose when using TKIs.
\end{abstract}

\section{Introduction}

Targeted therapies refer to the use of medication that blocks the growth of cancer cells by interfering with specific targeted molecules needed for carcinogenesis and tumor growth. During recent years, targeted therapies have been more frequently used to treat cancers. Some of the drugs used for targeted therapies have significant

Invited Author's profile

Bruno Vergès is Professor of Endocrinology and Diabetic Medicine at Dijon University and Chief of the Department of Endocrinology and Diabetology at the University Hospital of Dijon, France, where he has a clinical practice in endocrinology, diabetology and lipidology. He leads a research team dedicated to "Pathophysiology of dyslipidemias in humans" at the INSERM Research Center CRI 866. His major research interests are lipid abnormalities in insulin resistance and diabetes mellitus.

(c) 2014 European Society of Endocrinology Printed in Great Britain
Published by Bioscientifica Ltd. 
metabolic consequences, more particularly the mammalian target of rapamycin (mTOR) inhibitors and to a much lesser extent, the tyrosine kinase inhibitors (TKIs). Indeed, mTOR inhibitors, by interfering with the protein kinase mTOR pathway, which is also involved in glucose and lipid metabolism, are responsible for frequent dyslipidemia and hyperglycemia. Most of the TKIs have no significant effects on lipids and glucose metabolism. However, increasing evidence suggests that some TKIs, such as imatinib, sunitinib, pazopanib, or nilotinib, induce adverse reactions of hypoglycemia or hyperglycemia. We will consider in this review drugs currently approved by the Food and Drug Administration (FDA) in oncology with available phase III trial results but also data on mTOR inhibitors when used at the lowest doses as antirejection therapy for transplantation. Moreover, mTOR inhibitors also modify phospho-calcium metabolism. However, we will only consider their effects on lipid and glucose metabolism.

\section{Main indications for mTOR inhibitors and TKIs}

mTOR inhibitors were first used as anti-rejection agents for transplantation before being developed as targeted anti-cancer therapies (1). Both sirolimus (i.e. rapamycin) and everolimus are used as anti-rejection treatment while everolimus and temsirolimus are used as targeted anticancer therapies. Everolimus is used for both indications but with lower doses for anti-rejection (1.5-3.0 mg/day) than for anti-cancer (5-10 mg/day) treatment.

mTOR inhibitors are agents that inhibit signaling in the phosphoinositide 3-kinase (PI3K)-Akt-mTOR pathway, playing a key role in the regulation of cell growth. Although several compounds affecting this pathway are in various stages of clinical development, only two mTOR inhibitors (temsirolimus and everolimus) have been approved in oncology for marketing in the USA by the FDA. Everolimus is approved by the FDA for advanced progressive pancreatic neuroendocrine tumors (P-NETs) (2), advanced renal cell carcinoma (RCC) after failure of treatment with sunitinib or sorafenib (3), advanced hormone receptor-positive breast cancer in combination with exemestane (4), and for subependymal giant cell astrocytoma associated with tuberous sclerosis (5). Temsirolimus is approved by FDA in RCC (6) and mantle cell lymphoma (7).

TKIs are small molecules inhibiting tyrosine kinases that are enzymes playing an important role in the modulation of growth factor signaling. Imatinib is approved for treatment of chronic myeloid leukemia
(CML), philadelphia-positive $(\mathrm{Ph}+)$ acute lymphoblastic leukemia, chronic eosinophilic leukemia, and gastrointestinal stromal tumor (GIST) (8). Sunitinib is approved in second line for GIST (9), RCC (10), and recently for advanced P-NETs (11). Pazopanib is approved for advanced soft tissue sarcoma and RCC $(12,13)$. Nilotinib is approved for $\mathrm{Ph}+\mathrm{CML}$ (14).

\section{mTOR inhibitors}

Influence of mTOR on lipid and carbohydrate metabolism $\triangleright$ mTOR is a serine/threonine kinase, belonging to the PI3K-related kinase family, playing a key role in the regulation of cell growth as well as lipid and glucose metabolism. mTOR nucleates at least two distinct multiprotein complexes, mTOR complex 1 (mTORC1) and mTORC2 $(15,16)$. mTORC1 is composed of five subunits and regulates processes involved in the promotion of cell growth and metabolism. mTORC1 responds to amino acids (arginine and branched chain amino acids: leucine, isoleucine, and valine), stress, energy status, oxygen, and growth factors (including insulin). mTORC2, which is composed of six subunits, is activated by growth factors and regulates cell survival, cell metabolism, and cytoskeletal organization (Fig. 1).

Once activated, mTORC1 regulates many cellular processes. mTORC1 promotes protein synthesis by directly phosphorylating the translational regulators eukaryotic translation initiation factor 4E (eIF4E)-binding protein (4E-BP1) and S6 kinase 1 (S6K1) (17). In addition, mTORC1 controls growth by inhibiting autophagy (18), the central degradative process in cells. Finally, mTOR positively regulates cellular metabolism and ATP production by inducing the expression of many glycolytic genes, through the activation of the transcription factor hypoxia inducible factor $1 \alpha(19)$.

Compared with mTORC1, the functions of the mTORC2 pathway are poorly known. mTORC2 controls several protein kinases, including Akt/PKB, serum- and glucocorticoid-induced protein kinase 1 (SGK1), and protein kinase C (PKC)- $\alpha(20,21)$. By controlling Akt and SGK1, mTORC2 impacts cell growth/survival and metabolism, while it controls actin cytoskeleton dynamics by activating PKC- $\alpha$ (22).

The paradigm states that mTORC1, but not mTORC2, is sensitive to inhibition by rapamycin, although its exact mechanism of action remains unclear. The picture is less clear, however, because long-term treatment with rapamycin can also reduce mTORC2 signaling by suppressing mTORC2 assembly (23). 


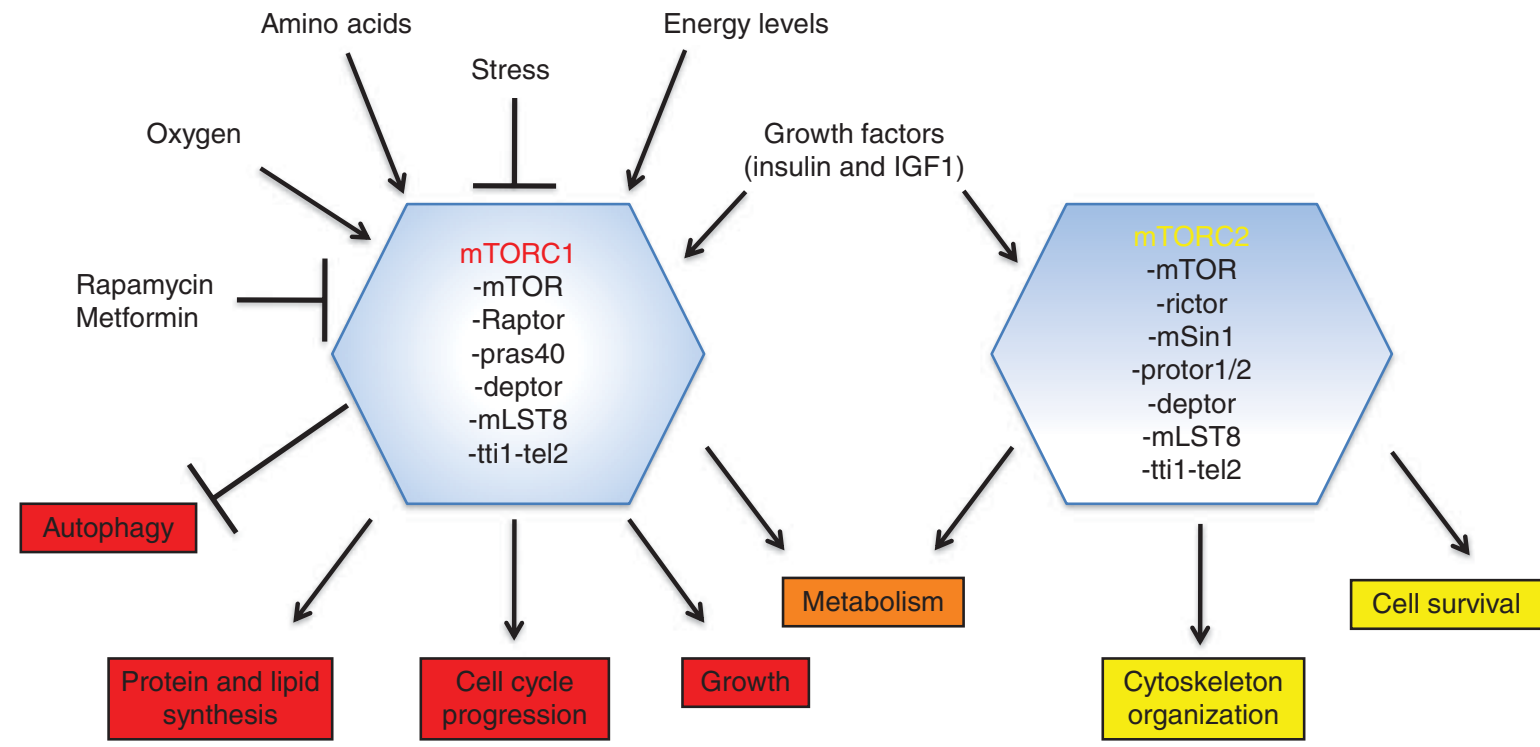

\section{Figure 1}

mTORC1 and mTORC2 complexes. mTORC1 is composed of six protein components and responds to various stimuli, such as amino acids, stress, growth factors, energy, and oxygen. mTORC1 is acutely inhibited by rapamycin and promotes cell growth by inducing anabolic processes and cell-cycle

mTOR and lipid metabolism $\vee$ mTORC1 controls lipid metabolism by different ways. Several data indicate that mTORC1 increases the activity of the transcription factor sterol regulatory element-binding protein-1c (SREBP-1c), which upregulates the expression of enzymes involved in lipogenesis (acetyl-CoA carboxylase, fatty acid synthase, and stearoyl-CoA desaturase). It has been shown that impairment of mTORC1 activity with rapamycin blocks the SREBP-1c induced expression of lipogenic enzymes (24). This is in line with data showing that rapamycin reduces the expression of SREBP-1c target genes such as acetyl-CoA carboxylase (25), fatty acid synthase (26), and stearoyl-CoA desaturase (27). Increased de novo lipid synthesis is an important feature of cancer cells and it is suggested that induction of lipid metabolism by SREBP-1c promotes cancer progression by providing lipids required for membranes. mTORC1 has been shown to increase PPAR $\gamma$ expression and then to promote adipogenesis (28). It has also been suggested that mTORC1 increases the activity of lipin 1, which is a phosphatidic acid phosphatase promoting triglyceride synthesis and enhancing the $\operatorname{PPAR} \gamma$ adipogenic activity (29). Lipin 1 has also been suggested to upregulate SREBP-1c expression and it has been shown in mice that inhibition of mTORC1 in the progression and inhibiting autophagy. mTORC2 is composed of seven protein components and is involved in cytoskeletal organization and cell survival. Both mTORC1 and mTORC2 are involved in metabolic homeostasis.

liver significantly impairs SREBP function in a lipin 1-dependent fashion (30).

So far, a possible implication of mTORC2 in the control of lipogenesis remains imprecise. Some data suggest that mTORC2 may control sphingolipid de novo synthesis by regulating the activity of the ceramide synthase (31), but further studies are needed to clarify the potential role of mTORC2 in the control of lipid metabolism.

mTOR and carbohydrate metabolism - The effects of mTOR on glucose homeostasis are complex with some opposite results depending on the level of mTORC1 activity (16). mTORC1 promotes insulin resistance in adipose tissue through the S6K1-mediated inhibition of insulin signaling, linked to the serine-phosphorylation of insulin receptor substrate 1 (IRS1) that disrupts the recruitment and activation of PI3K (32). The activity of mTORC1 is increased in insulin-target tissues (adipose tissue, skeletal muscle, and liver) of insulin-resistant rodents, reinforcing the hypothesis of a deleterious effect of sustained mTORs signaling on insulin sensitivity $(32,33,34)$. In the liver, the serine phosphorylation of IRS1 by mTORC1/S6K1 also leads to the impairment of the PI3K-Akt metabolic 
pathway, thereby promoting gluconeogenesis. Conversely, mTORC1 also plays a key role in the oxidative metabolism of skeletal muscle, as muscle-specific mTORC1 knockout mice display a muscle dystrophy with reduced muscle mass and oxidative function (35). In the liver, mTORC1 activity, which is reduced during fasting, inhibits ketogenesis by blunting the activity of $\operatorname{PPAR} \alpha$, the master transcriptional modulator of ketogenic genes (36).

mTORC1 also plays a central role in the regulation of the $\beta$-cell mass and function, which are some critical components in the pathogenesis of type 2 diabetes mellitus (T2DM). mTORC1 is a positive regulator of $\beta$-cell function, as constitutive activation of mTORC1 in $\beta$-cells improves insulin secretion and decreases blood glucose levels, and is linked to an increase in both $\beta$-cell size and number (37). Conversely, S6K1-deficient mice exhibit diminished $\beta$-cell size, hypoinsulinemia, and glucose intolerance (38). However, a sustained activation of mTORC1 in $\beta$-cells ultimately leads to an exhaustion of their insulin secreting capacity and to a deterioration of glucose homeostasis, by promoting apoptosis and reducing cell survival (39).

Effects of mTOR inhibitors on lipids $>$ The use of mTOR inhibitors is known to induce dyslipidemia. Indeed, a review of 17 randomized controlled trials shows an increase in total cholesterol and/or triglycerides in all but three trials (40). Among those three trials reporting no difference in lipids between groups, the percentage of mTOR inhibitor-treated patients on lipid lowering therapy were increased in two of them, indicating that mTOR inhibitors might have induced dyslipidemia $(41,42)$. In a study performed on 474 kidney transplant recipients, it was noted that dyslipidemia is frequent 1 year after transplantation and, in multivariate analysis, that treatment by mTOR inhibitors (sirolimus or everolimus) is an independent factor associated with dyslipidemia (43). As discussed later, dyslipidemia is also observed when mTOR inhibitors are used as targeted anti-cancer therapy.

Sirolimus (rapamycin) $>$ A significant increase in total cholesterol ranging from 25 to $55 \%$ has been observed with sirolimus (40, 41, 43, 44, 45, 46, 47, 48). In most clinical studies, sirolimus treatment is associated with a significant increase in LDL cholesterol $(40,43,47)$. In the study performed by Spinelli et al. (43), sirolimus treatment was an independent factor associated with plasma LDL cholesterol levels above $121 \mathrm{mg} / \mathrm{dl}$. It has also been reported that treatment with sirolimus is associated with a dramatic increase in plasma triglycerides ranging from
65 to $100 \%(41,42,43,44,45,47)$. Patients receiving sirolimus 2 or $5 \mathrm{mg} /$ day have been shown to have plasma triglycerides respectively 59 or $103 \mathrm{mg} / \mathrm{dl}$ greater than that of controls (41). In a multivariate analysis, sirolimus treatment was an independent factor associated with hypertriglyceridemia (43).

Plasma HDL cholesterol has been shown to be unchanged or slightly increased in clinical trials $(43,44$, $45,46,47)$. Thus, the detrimental effect of sirolimus on lipids is obvious and also confirmed by the fact that sirolimus-treated patients more frequently require adjunctive treatment with lipid lowering drugs (49). The hyperlipidemic effect of sirolimus is observed in the absence (50) and in the presence of ciclosporin $(48,49)$. In addition, data from the clinical studies indicate that the hyperlipidemic effect of sirolimus is dose-dependent $(41,49)$.

Everolimus $\bullet$ Increase in total cholesterol with everolimus has been reported in several studies $(3,43,44,50)$. In clinical trials which evaluated the efficacy of everolimus as anti-cancer therapy, hypercholesterolemia has been reported to be significantly more frequent with everolimus vs placebo $(3,50)$ (Table 1$)$. When measured, LDL cholesterol has been found to be increased with everolimus treatment (43).

Treatment with everolimus is associated with a significant increase in plasma triglycerides in most studies $(40,43,44,51,52)$. In the phase III trial evaluating everolimus in metastatic RCC, hypertriglyceridemia was significantly more frequent with everolimus $(71 \%)$ than with placebo (30\%) (3). In post-transplantation studies, an increase in plasma HDL cholesterol level from 15 to $21 \%$ has been reported $(43,44,45)$.

Several studies have pointed out some differences between everolimus and sirolimus as far as their lipid effects are concerned. A lower increase in plasma triglycerides with everolimus compared with sirolimus has been reported in two studies $(44,45)$, but not in the study performed by Spinelli et al. (43). Total cholesterol has been shown to be increased with sirolimus but not with everolimus (45). However, this different effect on cholesterol levels between the two drugs has not been found in other studies $(43,44)$. We have to say that the data comparing the lipid effects of the two drugs are limited and sometimes discrepant and do not allow drawing firm conclusions.

Temsirolimus $\checkmark$ Temsirolimus has also been reported to induce hyperlipidemia. In a phase III trial comparing 
Table 1 Incidence of hyperlipidemia and hyperglycemia induced by mTOR inhibitors in phase III studies.

\begin{tabular}{|c|c|c|c|c|c|c|c|c|}
\hline \multirow[b]{2}{*}{ Drug } & \multirow[b]{2}{*}{ Types of cancer } & \multirow[b]{2}{*}{$n$} & \multicolumn{2}{|c|}{ Hyperglycemia (\%) } & \multicolumn{2}{|c|}{ Hypercholesterolemia (\%) } & \multicolumn{2}{|c|}{ Hypertriglyceridemia (\%) } \\
\hline & & & All grades & Grades $3-4$ & All grades & Grades 3-4 & All grades & Grades 3-4 \\
\hline \multicolumn{9}{|l|}{ Everolimus } \\
\hline Everolimus & Renal cell carcinoma & 269 & 50 & 12 & 76 & 3 & 71 & $<1$ \\
\hline Placebo (3) & & 135 & 23 & 1 & 32 & 0 & 30 & 0 \\
\hline Everolimus & Pancreatic NETs & 204 & 13 & 5 & ND & ND & ND & ND \\
\hline Placebo (2) & & 203 & 4 & 2 & & & & \\
\hline Everolimus + Oct & $\begin{array}{l}\text { Gastrointestinal } \\
\text { NETs }\end{array}$ & 215 & 12 & 5 & 6 & ND & ND & ND \\
\hline Placebo+Oct (64) & & 211 & 2 & 0.5 & 1 & & & \\
\hline Everolimus & Breast & 482 & 13 & 4 & ND & ND & ND & ND \\
\hline Placebo (4) & & 238 & 2 & $<1$ & ND & ND & ND & ND \\
\hline Everolimus & $\begin{array}{l}\text { Subendymal giant } \\
\text { cell astrocytoma } \\
\text { with TBS }\end{array}$ & 78 & ND & ND & ND & ND & ND & ND \\
\hline Placebo (5) & & 39 & & & & & & \\
\hline \multicolumn{9}{|l|}{ Temsirolimus } \\
\hline Temsirolimus & Renal cell carcinoma & 208 & 26 & 11 & 24 & 1 & 27 & 3 \\
\hline Interferon & & 200 & 11 & 2 & 4 & 0 & 14 & 1 \\
\hline Temsi + interferon (6) & & 208 & 17 & 6 & 26 & 2 & 38 & 8 \\
\hline Temsirolimus + letrozole & Breast cancer & 550 & 13 & 4 & 12 & 1 & 11 & 2 \\
\hline Placebo + letrozole (53) & & 553 & 5 & 1 & 6 & $<0.5$ & 5 & $<0.5$ \\
\hline Temsirolimus & $\begin{array}{l}\text { Mantle cell } \\
\text { lymphoma }\end{array}$ & 108 & ND & ND & ND & ND & ND & ND \\
\hline Investigator's choice (7) & & 53 & ND & ND & ND & ND & ND & ND \\
\hline
\end{tabular}

NETs, neuroendocrine tumors; ND, not described (incidence are $<10 \%$ ); Oct, octreotide; TBS, tuberous sclerosis complex. Common terminology criteria for adverse events (CTCAE) grades for hyperglycemia: Grade 1, fasting blood glucose between 126 and $160 \mathrm{mg} / \mathrm{dl}$ (7.0-8.9 mmol/l); Grade 2, fasting blood glucose between 161 and $250 \mathrm{mg} / \mathrm{dl}$ (8.9-13.9 mmol/l); Grade 3, blood glucose between 251 and $500 \mathrm{mg} / \mathrm{dl}$ (13.9-27.8 mmol/l); Grade 4, blood glucose $>500 \mathrm{mg} / \mathrm{dl}(27.8 \mathrm{mmol} / \mathrm{l})$. CTAE grades for hypercholesterolemia: Grade 1, total cholesterol between the upper limit of the normal range and $300 \mathrm{mg} / \mathrm{dl}$ (7.75 mmol/l); Grade 2, total cholesterol between 301 and $400 \mathrm{mg} / \mathrm{dl}$ (7.76-10.34 mmol/l); Grade 3, total cholesterol between 401 and $500 \mathrm{mg} / \mathrm{dl}$ (10.35$12.92 \mathrm{mmol} / \mathrm{l})$; Grade 4, total cholesterol $>500 \mathrm{mg} / \mathrm{dl}(12.92 \mathrm{mmol} / \mathrm{l})$. CTAE grades for hypertriglyceridemia: Grade 1 , triglycerides between 150 and $300 \mathrm{mg} / \mathrm{dl}$ (1.71-3.42 mmol/l); Grade 2, triglycerides between 301 and $500 \mathrm{mg} / \mathrm{dl}$ (3.43-5.70 mmol/l); Grade 3, triglycerides between 501 and $1000 \mathrm{mg} / \mathrm{dl}$ (5.71-11.4 mmol/l); Grade 4, triglycerides $>1000 \mathrm{mg} / \mathrm{dl}(11.4 \mathrm{mmol} / \mathrm{l})$.

temsirolimus and interferon for treatment of advanced RCC, hypercholesterolemia was significantly more frequent with temsirolimus (24\%) than that with interferon (4\%) (6). Treatment of advanced breast cancer with temsirolimus in association with letrozole is responsible for twice more hypercholesterolemia (12\%) than treatment with letrozole alone (6\%) (53) (Table 1).

Pathophysiology of mTOR inhibitor-induced dyslipidemia $>$ The pathophysiology of mTOR inhibitor-induced dyslipidemia is not yet totally clear. In vitro studies have shown that mTOR inhibition by rapamycin increases fatty acids $\beta$-oxidation in the hepatocytes $(25,54)$ and skeletal muscles (55). In addition, several studies have shown that rapamycin reduces the gene expression of lipogenic enzymes such as acetyl-CoA carboxylase (25), fatty acid synthase (26), and stearoyl-CoA desaturase (27). In addition, rapamycin has been shown to promote fatty acid $\beta$-oxidation while decreasing fatty acid flux into anabolic storage pathways in primary cultures of rat hepatocytes, suggesting that the hyperlipidemia associated with rapamycin is not likely due to increased lipid hepatic synthesis but rather due to delayed peripheral clearance (25). Indeed, in kidney transplant recipients with sirolimus-induced hypertriglyceridemia, it has been shown with an in vivo kinetic study that hypertriglyceridemia was mostly due to decreased very-LDL (VLDL) catabolism (56). In that study, treatment with sirolimus was associated with a 70\% decrease in VLDL-apoB100 catabolism and a 28\% decrease in IDL-apoB100 catabolism (56). In line with these kinetic results, a significant decrease in post-heparin lipoprotein lipase (LPL) activity (the major enzyme responsible for triglyceride catabolism) was observed in patients showing sirolimus-induced hypertriglyceridemia (56) (Fig. 2). Interestingly, it has been shown that insulin upregulates LPL activity in a PI3Kdependent manner and that this regulation is decreased by $60 \%$ in the presence of rapamycin (57). In addition, treatment with rapamycin (sirolimus) is associated with a 92\% increase in apolipoprotein CIII, which is a potent inhibitor of LPL (47). Thus, all these data indicate that mTOR inhibitors are likely to decrease LPL activity and 


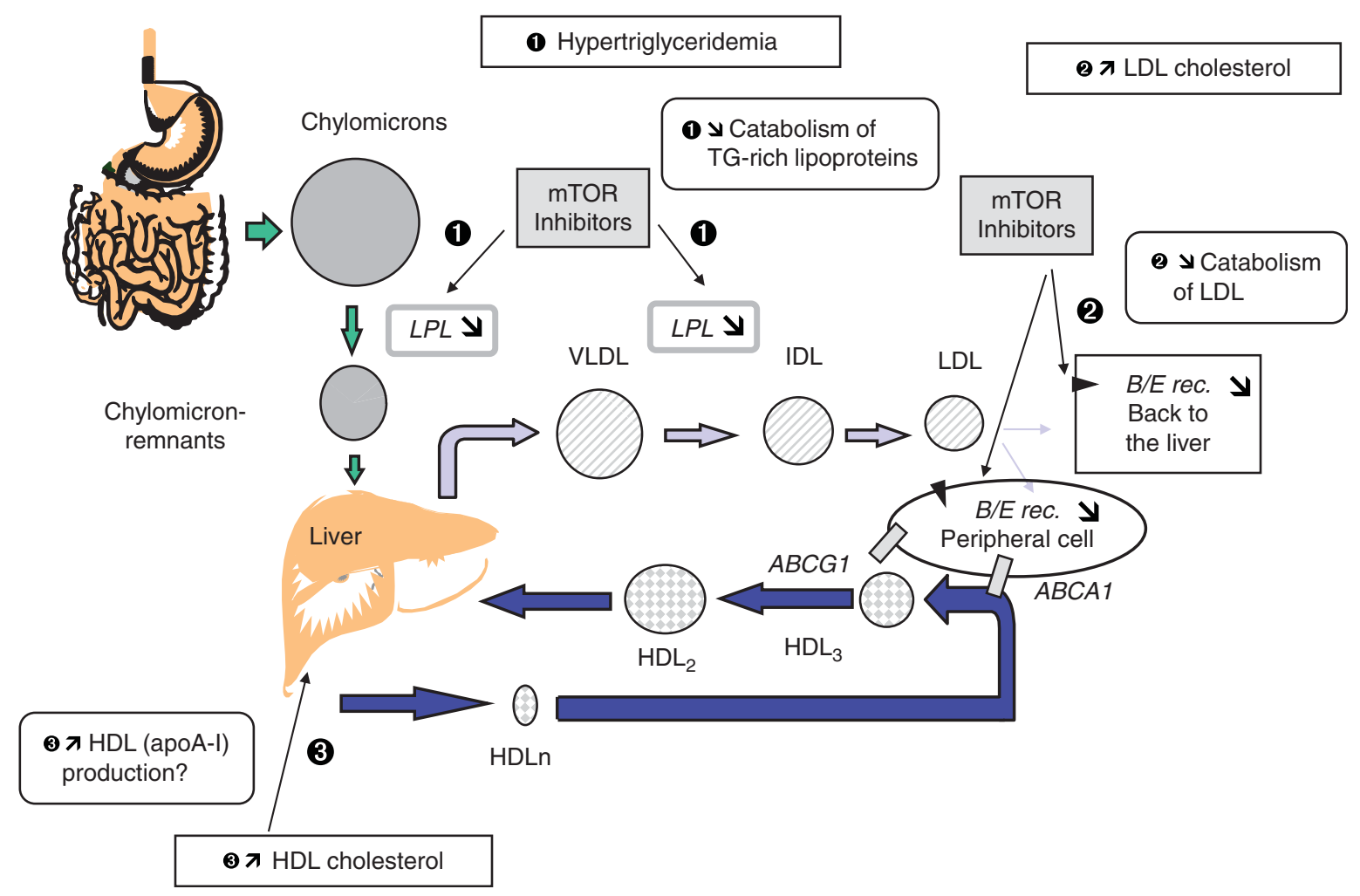

\section{Figure 2}

Pathophysiology of the dyslipidemia induced by mTOR inhibitors. VLDL, very-LDL; IDL, intermediate density lipoprotein; LPL, lipoprotein lipase; B/E rec., receptor B/E (LDL

thus to reduce the catabolism of triglyceride-rich lipoproteins leading to hypertriglyceridemia. It has also been shown that in renal transplant patients, treatment with sirolimus induced a $42 \%$ increase in free fatty acid pool, suggesting an augmented release of free fatty acids from the adipose tissue that may be due to a reduction of the inhibition of the hormone-sensitive lipase by insulin (47). It has been postulated that this increase in free fatty acids may increase hepatic VLDL production, but such increase in VLDL production has not been clearly shown in human kinetic studies (56).

As far as LDL cholesterol is concerned, a kinetic study performed in renal transplant patients has shown that treatment with sirolimus was associated with a $68 \%$ decrease in LDL-apoB100 catabolism (56). It has been shown in vitro with HepG2 cells that sirolimus reduced LDL receptor (LDLr) expression leading to diminished LDL uptake (58) (Fig. 2). This inhibitory effect is mediated by the downregulation of SREBP cleavage activating protein (SCAP) and SREBP-2 mRNA and by reduced translocation receptor); $A B C A 1$, ATP-binding cassette transporter $A 1 ; A B C G 1$, ATP-binding cassette transporter G1; TG, triglycerides.

of SCAP-SREBP-2 complex from endoplasmic reticulum to Golgi for activation, thereby reducing LDLr gene transcription (58). Proprotein convertase subtilisin kexin type 9 (PCSK9) is an endogenous inhibitor of the LDLr (for review see (59)). Interestingly, a recent report has demonstrated that rapamycin increased expression of PCSK9, decreased levels of hepatic LDLr protein, and finally increased levels of VLDL/LDL cholesterol in WT but not in PCSK9 knockout mice (60). These results suggest that PCSK9 could be a molecular link for the mTOR inhibitor-induced dyslipidemia.

So far, the mechanisms responsible for increased plasma HDL cholesterol observed with everolimus and sometimes with sirolimus are not known. In one study, an inconstant increase in plasma apoA-I, the major apolipoprotein of HDL, was observed but it did not totally parallel the increase in HDL cholesterol (47). To date, no clear hypotheses can be made to explain the increase of HDL cholesterol with mTOR inhibitors and studies are needed to clarify this point. 
Effects of mTOR inhibitors on glycemia - The perturbation in glucose homeostasis with mTOR inhibitors is the second main metabolic complication for this class of drugs.

Sirolimus (rapamycin) $\triangleright$ The first data came from the use of sirolimus as immunosuppressive agent in patients with kidney transplant, demonstrating that sirolimus can induce new-onset diabetes in this population, especially when the drug is used in association with calcineurin inhibitors (61). For instance, the 3-year cumulative incidence of new onset-diabetes was $21.9 \%$ in patients treated by the combination of sirolimus and ciclosporin A $(n=800)$ and $21.5 \%$ in those with sirolimus and tacrolimus ( $n=1179)$ (62). In this study, treatment with sirolimus was independently associated with a risk of new-onset diabetes (62). A more direct proof of the direct deleterious effect of sirolimus on glucose homeostasis comes from a small pilot study assessing the metabolic consequences of the withdrawal of calcineurin inhibitors (ciclosporin A or tacrolimus) and the switch to sirolimus in 41 adult kidney transplant recipients. The switch to sirolimus led to a $30 \%$ increase in the incidence of impaired glucose tolerance and to new-onset diabetes mellitus in four patients (63).

Everolimus and temsilorimus $\triangleright$ A same tendency for a deterioration of glucose homeostasis is observed when mTOR inhibitors are used as anti-cancer agents. The frequency of hyperglycemia was assessed in randomized trials as an adverse event listed in the Common Terminology Criteria for Adverse Events (see Table 1). Hyperglycemia was reported in $12-50 \%$ of patients in phase III studies for everolimus $(2,3,4,5,64)$ and temsirolimus, but grades 3-4 (G3-4) hyperglycemic events (>13.9 mmol/1) were less frequent (4-22\%) (Table 1).

However, all these studies did not report the percentage of patients treated with glucose-lowering agents and their dose. Moreover, these studies did not reflect the real life of patients treated by mTOR inhibitors, as patients with uncontrolled diabetes were excluded in these trials. One can suspect that that the incidence of hyperglycemia might be different according to the treated cancer with, for instance, a higher proportion of diabetes in P-NETs, which in theory are more likely to induce diabetes. However, this is not really the case as, in clinical trials, the highest frequency of diabetes has been found in patients with advanced RCC $(3,6)$. For instance, in the RADIANT-3 study of treatment with everolimus in patients with advanced P-NETs, $13 \%$ of treated patients exhibited hyperglycemia (with 5\% G3-4), compared with 4 and $2 \%$ in the placebo group respectively (2). In comparison, hyperglycemia appears to be more frequent in patients with advanced RCC, as $50 \%$ of everolimus-treated patients exhibited hyperglycemic events in the RECORD-1 trial compared with $23 \%$ in the placebo group (3). This indicates that hyperglycemia induced by mTOR inhibitors is observed independently of the origin of treated cancer.

Pathophysiology of hyperglycemia induced by mTOR inhibitors $>$ The role of mTOR pathway and its manipulation with mTOR inhibitors is undoubtedly complex. Notably, there are some still unexplained discrepancies between both in vitro and in vivo preclinical studies on rodents and clinical data from phase II/III study with everolimus on humans.

It seems that mTOR inhibitors exert a 'Janus effect' on glucose metabolism. Indeed, based on the observation that chronic activation of mTORC1 promotes insulin resistance, it could be hypothesized that the chronic inhibition of the mTOR pathway could improve glucose homeostasis. As suggested by Laplante \& Sabatini (16), the relation between mTORC1 activity and metabolic homeostasis probably follows a U-shaped curve, where too little or too much mTORC1 activity has a deleterious effect on systemic metabolism (Fig. 3). In addition, it has been demonstrated very recently that the duration of mTOR inhibition with rapamycin is of critical importance for regulating metabolic homeostasis (65). While short-term treatment with rapamycin exerts detrimental effects on glucose homeostasis in mice, prolonged treatment (i.e. 20 weeks) is associated with enhanced insulin sensitivity, increased energy expenditure, and better lipid profile (65). Notably, the antidiabetic drug metformin might improve glucose homeostasis by partially inhibiting mTORC1 signaling $(16,65)$. Thus, the metabolic effects of treatment with rapamycin have been assessed in several rodent models. Unexpectedly, rapamycin leads to the aggravation of glucose homeostasis with the development of T2DM, linked to a combination of an impaired insulin secretion and severe insulin resistance $(67,68)$. Moreover, it has been shown recently that chronic treatment with rapamycin disrupts mTORC2 complex and blocks its inhibiting activity on hepatic gluconeogenesis (69). Similar results were observed with a selective mTOR kinase inhibitor AZD8055, with an increase in blood glucose levels in treated mice (70). In humans, long-term treatment with rapamycin impaired insulin signaling assessed by the phosphorylation of Akt in circulating mononuclear cells (PBMC) of kidney- 


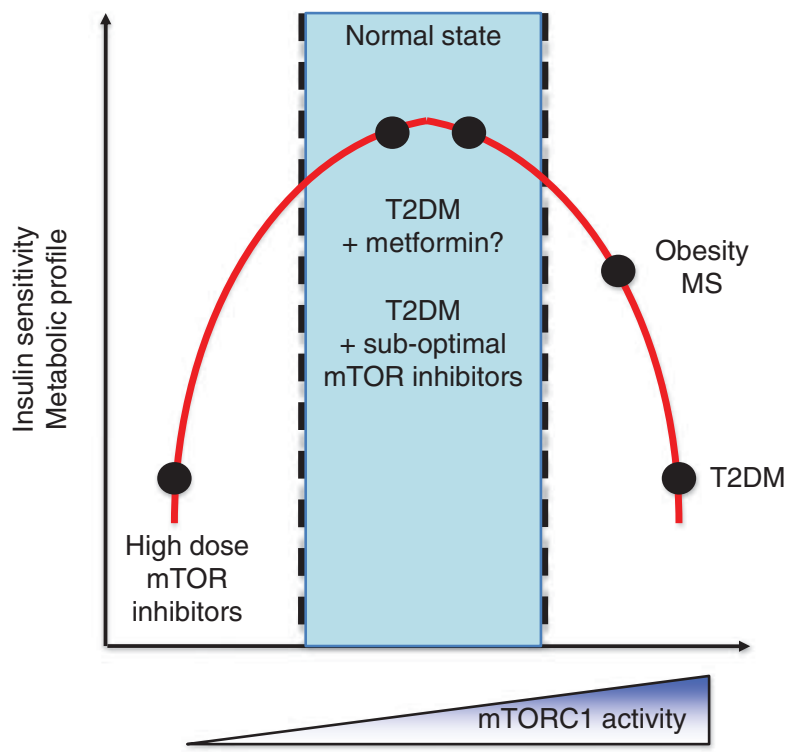

Figure 3

Relationship between mTORC1 activity and metabolic homeostasis. The U-shaped curve indicates that too little or too much mTORC1 activity is associated with insulin resistance and altered metabolic profile. MS, metabolic syndrome; T2DM, type 2 diabetes mellitus. Adapted from Laplante M \& Sabatini DM. mTOR signaling in growth control and disease. Cell 2012149 274-293.

transplanted patients (71). In accordance with an impairment of insulin signaling, insulin-stimulated glucose uptake was reduced in human adipocytes treated for a short-term (15 min) or long-term treatment $(20 \mathrm{~h})$ with rapamycin at therapeutic concentrations (72). At the whole body level, the switch of calcineurin inhibitors to sirolimus induces a worsening of insulin resistance associated with a deterioration of compensatory insulin secretion, leading to new-onset diabetes (63). Interestingly, Kulke et al. (72) first reported in 2009 that the use of everolimus in four patients with insulinoma and refractory hypoglycemia was associated with improved glycemic control. This 'beneficial' hyperglycemic effect of mTOR inhibitors in patients with metastatic insulinoma has since been confirmed in a large size study (73). This effect of mTOR inhibitors in cases of severe insulinoma is another proof of the hyperglycemic effect of this therapeutic class.

\section{Tyrosine kinase inhibitors}

TKIs and lipids $\downarrow$ TKIs seem to have limited effect on lipids. The phase III trials with TKI did not show any hyperlipidemic effects. Interestingly, correction of hyperlipidemia has been reported in hyperlipidemic patients treated with imatinib for either CML or hypereosinophilic syndrome (74). In this study, among nine patients with hypercholesterolemia, not treated with hypolipidemic agents, eight of them normalized their plasma cholesterol 30 days after starting treatment with imatinib, with a significant decrease in mean plasma total cholesterol from 254 to $176 \mathrm{mg} / \mathrm{dl}$ (74). In addition, four of these nine patients also had hypertriglyceridemia and three of them normalized their plasma triglycerides with a significant decrease in mean plasma triglycerides from 264 to $130 \mathrm{mg} / \mathrm{dl}$ (74). The reasons for this corrective effect of imatinib on hyperlipidemia are not clear. It has been suggested that imatinib, by inhibiting the platelet-derived growth factor, may then reduce the cytoplasmic phosphorylation of LDLr-related protein which is involved in lipid metabolism.

TKIs and glucose homeostasis - TKIs influence glucose metabolism, with both elevated and decreased blood glucose levels that have been attributed to TKI treatment. The molecular mechanism by which TKI controls glucose homeostasis remains unknown. More disturbing is the observation that the same TKI (for instance, imatinib or sunitinib) can be associated either with hyperglycemic or hypoglycemic events (75). Hyperglycemia has been reported with sunitinib in $15 \%$ of patients with metastatic RCC (10), while it was not reported in phase III trials of patients with advanced P-NETs or GIST (Table 2). In contrast, some patients treated by imatinib or sunitinib also presented hypoglycemia and/or regression of longstanding diabetes $(12,76,77,78,79,80)$. Among TKIs, the main drug causing hyperglycemia is nilotinib (Table 2). Hyperglycemia is reported as a common adverse event in its prescribing information form, occurring in 38\% of patients (G3-4 $=5 \%$ ) with CML treated by nilotinib in the phase III trials (14). Owing to their unpredictable action on blood glucose levels, a tight monitoring of glucose homeostasis (with at least HbA1c dosage and selfmonitoring of blood glucose if necessary) is required in patients under TKI. It should also be recommended that patients are educated to recognize any symptomatic sign of hypoglycemia or hyperglycemia (e.g. thirst, polyuria).

It should also be mentioned that nilotinib was found to be associated with severe progressive peripheral arterial occlusive disease and, to a lesser extent, with other vascular occlusive events (myocardial infarction and stroke) (81). The underlying molecular mechanism 
Table 2 Incidence of hyperglycemia and hypoglycemia induced by tyrosine kinase inhibitor (TKI) in phase III studies.

\begin{tabular}{|c|c|c|c|c|c|c|}
\hline \multirow[b]{2}{*}{ Drug } & \multirow[b]{2}{*}{ Types of cancer } & \multirow[b]{2}{*}{$n$} & \multicolumn{2}{|c|}{ Hyperglycemia (\%) } & \multicolumn{2}{|c|}{ Hypoglycemia (\%) } \\
\hline & & & All grades & Grades 3-4 & All grades & Grades 3-4 \\
\hline \multicolumn{7}{|l|}{ Nilotinib } \\
\hline Nilotinib & Chronic myeloid leukemia & 556 & 38 & 5 & ND & ND \\
\hline Imatinib (14) & & 280 & 20 & 0 & ND & ND \\
\hline Nilotinib & Gastrointestinal stromal tumor & 165 & ND & ND & ND & ND \\
\hline Control (84) & & 83 & ND & ND & ND & ND \\
\hline \multicolumn{7}{|l|}{ Pazopanib } \\
\hline Pazopanib & Renal cell carcinoma & 290 & 41 & 2 & 17 & 1 \\
\hline Placebo (12) & & 145 & 33 & 1 & 3 & 0 \\
\hline Pazopanib & Soft tissue sarcoma & 239 & ND & ND & ND & ND \\
\hline Placebo (13) & & 123 & ND & ND & ND & ND \\
\hline \multicolumn{7}{|l|}{ Sunitinib } \\
\hline Sunitinib & Renal cell carcinoma & 375 & 15 & & & \\
\hline Interferon $\alpha(10)$ & & 360 & & & & \\
\hline Sunitinib & Pancreatic NETs & 83 & ND & ND & ND & ND \\
\hline Placebo (11) & & 82 & ND & ND & ND & ND \\
\hline Sunitinib & Gastrointestinal stromal tumor & 202 & ND & ND & ND & ND \\
\hline Placebo (9) & & 102 & ND & ND & ND & ND \\
\hline
\end{tabular}

NETs, neuroendocrine tumors; ND, not described (incidence are $<10 \%$ ). Common terminology criteria for adverse events (CTCAE) grades for hyperglycemia: Grade 1, fasting blood glucose between 126 and $160 \mathrm{mg} / \mathrm{dl}(7.0-8.9 \mathrm{mmol} / \mathrm{l}) ; \mathrm{Grade} 2$, fasting blood glucose between 161 and $250 \mathrm{mg} / \mathrm{dl}$ (8.9-13.9 mmol/l); Grade 3, blood glucose between 251 and $500 \mathrm{mg} / \mathrm{dl}$ (13.9-27.8 mmol/l); Grade 4, blood glucose $>500 \mathrm{mg} / \mathrm{dl}$ ( $27.8 \mathrm{mmol} / \mathrm{l})$. CTCAE grades for hypoglycemia: Grade 1, blood glucose between $55 \mathrm{mg} / \mathrm{dl}(3 \mathrm{mmol} / \mathrm{l})$ and the lower limit of the normal range; Grade 2 , blood glucose between 40 and $54 \mathrm{mg} / \mathrm{dl}$ ( $2.2-$ $2.9 \mathrm{mmol} / \mathrm{l})$; Grade 3, blood glucose between 30 and $39 \mathrm{mg} / \mathrm{dl}(1.7-2.1 \mathrm{mmol} / \mathrm{l}) ;$ Grade 4, blood glucose $<30 \mathrm{mg} / \mathrm{dl}$ (1.7 mmol/l).

remains unclear, but these arterial events seem to occur in patients with cardiovascular (CV) risk factors (82).

\section{Metabolic consequences of anti-cancer targeted therapies in clinical practice}

The main modifications of plasma lipids and glycemia with mTOR inhibitors and TKI are listed in Table 3. Owing to the significant effect of mTOR inhibitors on lipid and glucose metabolism, a specific management of mTORinduced lipid disorders or hyperglycemia has been recently proposed by a Task Force of the US National Cancer Institute Investigational Drug Steering Committee (54) and a French expert committee (83).

Before initiation of a treatment with an mTOR inhibitor, it is recommended to measure fasting lipids (total cholesterol, triglycerides, and HDL cholesterol), fasting plasma glucose (FPG), and HbA1c. LDL cholesterol level will be calculated using the Friedewald formula (LDL cholesterol $=$ total cholesterol - HDL cholesterol - triglycerides/5 (mg/dl)). In case of plasma triglycerides above $400 \mathrm{mg} /$ day $(4.56 \mathrm{mmol} / \mathrm{l})$, the Friedewald formula may not be used and a direct measurement of LDL cholesterol or plasma apoB will be required.

When an abnormal lipid profile (elevated LDL cholesterol and elevated triglycerides) is present at baseline, it is recommended to initiate an appropriate hypolipidemic treatment before starting the mTOR inhibitor therapy. If the baseline lipid profile is normal, fasting lipid levels will have to be checked every 2 weeks during the first mTOR inhibitor treatment cycle and then with every mTOR inhibitor treatment cycle. During treatment with mTOR inhibitor, a treatment with statin will have to be initiated if plasma LDL cholesterol is above $190 \mathrm{mg} / \mathrm{dl}(4.90 \mathrm{mmol} / \mathrm{l})$ when one or no CV risk factors are present (age $>50$ for male, age $>60$ for female, family history of coronary artery disease, hypertension, diabetes, smoking, HDL cholesterol $<40 \mathrm{mg} / \mathrm{dl}$ or $1.0 \mathrm{mmol} / \mathrm{l}$ ) or above $130 \mathrm{mg} / \mathrm{dl}(3.35 \mathrm{mmol} / \mathrm{l})$ when two or more $\mathrm{CV}$ risk factors are present, or above $100 \mathrm{mg} / \mathrm{dl}(2.58 \mathrm{mmol} / \mathrm{l})$ in case of history of previous $\mathrm{CV}$ disease. The recommended LDL cholesterol goals are $<130 \mathrm{mg} / \mathrm{dl}$ (3.35 mmol/l) when

Table 3 Modification of plasma lipids and glycemia with mTOR inhibitors and tyrosine kinase inhibitors (TKIs).

\begin{tabular}{|c|c|c|}
\hline & mTOR inhibitors & TKIs \\
\hline Total cholesterol & $\uparrow$ & $\begin{array}{r}\leftrightarrow(\downarrow \text { in one study } \\
\quad \text { with imatinib) }\end{array}$ \\
\hline Triglycerides & $\uparrow$ & $\begin{array}{r}\leftrightarrow(\downarrow \text { in one study } \\
\quad \text { with imatinib) }\end{array}$ \\
\hline $\begin{array}{l}\text { LDL cholesterol } \\
\text { HDL cholesterol }\end{array}$ & $\leftrightarrow$ or $\uparrow$ & \\
\hline Glycemia & $\uparrow$ & $\uparrow$ or $\downarrow$ \\
\hline
\end{tabular}


one or no $\mathrm{CV}$ risk factors are present or $<100 \mathrm{mg} / \mathrm{dl}$ $(2.58 \mathrm{mmol} / \mathrm{l})$ when two or more $\mathrm{CV}$ risk factors or history of previous $\mathrm{CV}$ disease are present (84). It is recommended to use pravastatin, fluvastatin, or rosuvastatin in patients on mTOR inhibitor therapy. The use of simvastatin or atorvastatin is not recommended because they may interact with mTOR inhibitors (via competitive inhibition of cytochrome P 3A4).

Patients on mTOR inhibitor therapy showing fasting plasma triglycerides above $400 \mathrm{mg} /$ day (4.56 mmol/l) should be instructed in therapeutic lifestyle changes including limitation of alcohol and high-sugar food. LDL cholesterol-lowering therapy with a statin will have to be considered if plasma LDL cholesterol is above the recommended level (see above). If plasma triglycerides remain elevated (above $400 \mathrm{mg} / \mathrm{dl}$ or $4.56 \mathrm{mmol} / \mathrm{l})$, a treatment with fenofibrate and/or omega 3 fatty acids should be considered, because of the risk for acute pancreatits.

As far as glucose metabolism is concerned, baseline measurement of FPG and HbA1c will allow to diagnose patients with prediabetes (FPG, 110-126 mg/dl or $6.0-7.0 \mathrm{mmol} / \mathrm{l}$; HbA1c, $6.0-6.4 \%$ ) or diabetes (FPG, $\geq 126 \mathrm{mg} / \mathrm{dl}$ or $7.0 \mathrm{mmol} / \mathrm{l}$; HbA1c, $\geq 6.5 \%$ ). In normoglycemic patients, FPG should be checked every 2 weeks during the first month of treatment and then monthly. In addition, HbA1c will be measured every 3 months in all patients. In patients with prediabetes and/or metabolic syndrome, once-daily self-monitoring blood glucose (SMBG) assessment should be recommended. For the patients with known diabetes, SMBG should be intensified. It is recommended to initiate a treatment with metformin, the first-line drug for management of hyperglycemia, when FPG is above $126 \mathrm{mg} / \mathrm{dl}$ (7.0 mmol/l), when plasma glucose is above $200 \mathrm{mg} / \mathrm{dl}$ at any time, or when HbA1c is above $6.5 \%$. The recommended HbA1c target for these patients is between 7.0 and $8.0 \%$. Ketonuria should be checked when blood glucose $>250 \mathrm{mg} / \mathrm{dl}$ to early diagnose diabetic ketoacidosis. When plasma glucose is above $250 \mathrm{mg} / \mathrm{dl}(13.8 \mathrm{mmol} / \mathrm{l})$, patients should rapidly be referred to an endocrinologist or diabetologist for the management of hyperglycemia (84).

Because treatment with TKI may be associated with hypo- or hyperglycemia, it is recommend to measure FPG and HbA1c before initiating the TKI treatment. FPG will be checked every 2 weeks during the first month and then once every month. HbA1c will be measured every 3 months. In a patient with known diabetes, SMBG will be reinforced.

\section{Conclusion}

Targeted therapies are widely used in oncology for the treatment of a variety of malignancies. Considering the results from the phase III trials, it is obvious that some of these targeted therapies, especially mTOR inhibitors, are associated with an increased risk of metabolic complications. This risk should be anticipated by the identification of high-risk patients and managed by a close monitoring of metabolic parameters, in tight collaboration with physicians specialized in diabetes and endocrinology.

Declaration of interest

The authors declare that there is no conflict of interest that could be perceived as prejudicing the impartiality of the review reported.

\section{Funding}

This review did not receive any specific grant from any funding agency in the public, commercial or not-for-profit sector.

\section{References}

1 Touzot M, Soulillou JP \& Dantal J. Mechanistic target of rapamycin inhibitors in solid organ transplantation: from benchside to clinical use. Current Opinion in Organ Transplantation 201217 626-633. (doi:10.1097/MOT.0b013e32835a4be2)

2 Yao JC, Shah MH, Ito T, Bohas CL, Wolin EM, Van Cutsem E, Hobday TJ, Okusaka T, Capdevila J, de Vries EG et al. Everolimus for advanced pancreatic neuroendocrine tumors. New England Journal of Medicine 2011364 514-523. (doi:10.1056/NEJMoa1009290)

3 Motzer RJ, Escudier B, Oudard S, Hutson TE, Porta C, Bracarda S, Grünwald V, Thompson JA, Figlin RA, Hollaender N et al. Efficacy of everolimus in advanced renal cell carcinoma: a double-blind, randomised, placebo-controlled phase III trial. Lancet 2008372 449-456. (doi:10.1016/S0140-6736(08)61039-9)

4 Baselga J, Campone M, Piccart M, Burris HA III, Rugo HS, Sahmoud T, Noguchi S, Gnant M, Pritchard KI, Lebrun F et al. Everolimus in postmenopausal hormone-receptor-positive advanced breast cancer. New England Journal of Medicine 2012366 520-529. (doi:10.1056/ NEJMoa1109653)

5 Franz DN, Belousova E, Sparagana S, Bebin EM, Frost M, Kuperman R, Witt O, Kohrman MH, Flamini JR, Wu JY et al. Efficacy and safety of everolimus for subependymal giant cell astrocytomas associated with tuberous sclerosis complex (EXIST-1): a multicentre, randomised, placebo-controlled phase 3 trial. Lancet 2013381 125-132. (doi:10.1016/S0140-6736(12)61134-9)

6 Hudes G, Carducci M, Tomczak P, Dutcher J, Figlin R, Kapoor A, Staroslawska E, Sosman J, McDermott D, Bodrogi I et al. Temsirolimus, interferon alfa, or both for advanced renal-cell carcinoma. New England Journal of Medicine 2007356 2271-2281. (doi:10.1056/NEJMoa066838)

7 Hess G, Herbrecht R, Romaguera J, Verhoef G, Crump M, Gisselbrecht C, Laurell A, Offner F, Strahs A, Berkenblit A et al. Phase III study to evaluate temsirolimus compared with investigator's choice therapy for the treatment of relapsed or refractory mantle cell lymphoma. Journal of Clinical Oncology 200927 3822-3829. (doi:10.1200/JCO.2008.20.7977) 
8 Dematteo RP, Ballman KV, Antonescu CR, Maki RG, Pisters PW, Demetri GD, Blackstein ME, Blanke CD, von Mehren M, Brennan MF et al. Adjuvant imatinib mesylate after resection of localised, primary gastrointestinal stromal tumour: a randomised, double-blind placebo-controlled trial. Lancet 2009373 1097-1104. (doi:10.1016/ S0140-6736(09)60500-6)

9 Demetri GD, van Oosterom AT, Garrett CR, Blackstein ME, Shah MH, Verweij J, McArthur G, Judson IR, Heinrich MC, Morgan JA et al. Efficacy and safety of sunitinib in patients with advanced gastrointestinal stromal tumour after failure of imatinib: a randomised controlled trial. Lancet 2006368 1329-1338. (doi:10.1016/S0140-6736 (06)69446-4)

10 Motzer RJ, Hutson TE, Tomczak P, Michaelson MD, Bukowski RM, Rixe O, Oudard S, Negrier S, Szczylik C, Kim ST et al. Sunitinib versus interferon alfa in metastatic renal-cell carcinoma. New England Journal of Medicine 2007356 115-124. (doi:10.1056/NEJMoa065044)

11 Raymond E, Dahan L, Raoul JL, Bang YJ, Borbath I, Lombard-Bohas C, Valle J, Metrakos P, Smith D, Vinik A et al. Sunitinib malate for the treatment of pancreatic neuroendocrine tumors. New England Journal of Medicine 2011364 501-513. (doi:10.1056/NEJMoa1003825)

12 Sternberg CN, Davis ID, Mardiak J, Szczylik C, Lee E, Wagstaff J, Barrios CH, Salman P, Gladkov OA, Kavina A et al. Pazopanib in locally advanced or metastatic renal cell carcinoma: results of a randomized phase III trial. Journal of Clinical Oncology 201028 1061-1068. (doi:10.1200/JCO.2009.23.9764)

13 van der Graaf WT, Blay JY, Chawla SP, Kim DW, Bui-Nguyen B, Casali PG, Schöffski P, Aglietta M, Staddon AP, Beppu Y et al. Pazopanib for metastatic soft-tissue sarcoma (PALETTE): a randomised, doubleblind, placebo-controlled phase 3 trial. Lancet 2012379 1879-1886. (doi:10.1016/S0140-6736(12)60651-5)

14 Saglio G, Kim DW, Issaragrisil S, le Coutre P, Etienne G, Lobo C, Pasquini R, Clark RE, Hochhaus A, Hughes TP et al. Nilotinib versus imatinib for newly diagnosed chronic myeloid leukemia. New England Journal of Medicine 2010362 2251-2259. (doi:10.1056/ NEJMoa0912614)

15 Guertin DA \& Sabatini DM. Defining the role of mTOR in cancer. Cancer Cell 2007 12 9-22. (doi:10.1016/j.ccr.2007.05.008)

16 Laplante M \& Sabatini DM. mTOR signaling in growth control and disease. Cell 2012149 274-293. (doi:10.1016/j.cell.2012.03.017)

$17 \mathrm{Ma}$ XM \& Blenis J. Molecular mechanisms of mTOR-mediated translational control. Nature Reviews. Molecular Cell Biology 200910 307-318. (doi:10.1038/nrm2672)

18 Ganley IG, Lam DH, Wang J, Ding X, Chen S \& Jiang X ULK1.ATG13.FIP200 complex mediates mTOR signaling and is essential for autophagy. Journal of Biological Chemistry 2009284 12297-12305. (doi:10.1074/jbc.M900573200)

19 Hudson CC, Liu M, Chiang GG, Otterness DM, Loomis DC, Kaper F, Giaccia AJ \& Abraham RT. Regulation of hypoxia-inducible factor $1 \propto$ expression and function by the mammalian target of rapamycin. Molecular and Cellular Biology 200222 7004-7014. (doi:10.1128/ MCB.22.20.7004-7014.2002)

20 Sarbassov DD, Guertin DA, Ali SM \& Sabatini DM. Phosphorylation and regulation of Akt/PKB by the rictor-mTOR complex. Science 2005 307 1098-1101. (doi:10.1126/science.1106148)

21 García-Martínez JM \& Alessi DR. mTOR complex 2 (mTORC2) controls hydrophobic motif phosphorylation and activation of serumand glucocorticoid-induced protein kinase 1 (SGK1). Biochemical Journal 2008416 375-385. (doi:10.1042/BJ20081668)

22 Jacinto E, Loewith R, Schmidt A, Lin S, Rüegg MA, Hall A \& Hall MN. Mammalian TOR complex 2 controls the actin cytoskeleton and is rapamycin insensitive. Nature Cell Biology 20046 1122-1128. (doi:10.1038/ncb1183)

23 Sarbassov DD, Ali SM, Sengupta S, Sheen J-H, Hsu PP, Bagley AF, Markhard AL \& Sabatini DM. Prolonged rapamycin treatment inhibits mTORC2 assembly and Akt/PKB. Molecular Cell 200622 159-168. (doi:10.1016/j.molcel.2006.03.029)
24 Porstmann T, Santos CR, Griffiths B, Cully M, Wu M, Leevers S, Griffiths JR, Chung YL \& Schulze A. SREBP activity is regulated by mTORC1 and contributes to Akt-dependent cell growth. Cell Metabolism 20088 224-236. (doi:10.1016/j.cmet.2008.07.007)

25 Brown NF, Stefanovic-Racic M, Sipula IJ \& Perdomo G. The mammalian target of rapamycin regulates lipid metabolism in primary cultures of rat hepatocytes. Metabolism 200756 1500-1507. (doi:10.1016/j. metabol.2007.06.016)

26 Peng T, Golub TR \& Sabatini DM. The immunosuppressant rapamycin mimics a starvation-like signal distinct from amino acid and glucose deprivation. Molecular and Cellular Biology 200222 5575-5584. (doi:10.1128/MCB.22.15.5575-5584.2002)

27 Mauvoisin D, Rocque G, Arfa O, Radenne A, Boissier P \& Mounier C. Role of the PI3-kinase/mTor pathway in the regulation of the stearoyl CoA desaturase (SCD1) gene expression by insulin in liver. Journal of Cell Communication and Signaling 20071 113-125. (doi:10.1007/ s12079-007-0011-1)

28 Zhang HH, Huang J, Düvel K, Boback B, Wu S, Squillace RM, Wu CL \& Manning BD. Insulin stimulates adipogenesis through the Akt-TSC2mTORC1 pathway. PLoS ONE 20094 e6189. (doi:10.1371/journal. pone.0006189)

29 Huffman TA, Mothe-Satney I \& Lawrence JC. Insulin-stimulated phosphorylation of lipin mediated by the mammalian target of rapamycin. PNAS 200299 1047-1052. (doi:10.1073/pnas.022634399)

30 Peterson TR, Sengupta SS, Harris TE, Carmack AE, Kang SA, Balderas E, Guertin DA, Madden KL, Carpenter AE, Finck BN et al. mTOR complex 1 regulates lipin 1 localization to control the SREBP pathway. Cell 2011 146 408-420. (doi:10.1016/j.cell.2011.06.034)

31 Aronova S, Wedaman K, Aronov PA, Fontes K, Ramos K, Hammock BD $\&$ Powers T. Regulation of ceramide biosynthesis by TOR complex 2 . Cell Metabolism 20087 148-158. (doi:10.1016/j.cmet.2007.11.015)

32 Um SH, Frigerio F, Watanabe M, Picard F, Joaquin M, Sticker M, Fumagalli S, Allegrini PR, Kozma SC, Auwerx J et al. Absence of S6K1 protects against age- and diet-induced obesity while enhancing insulin sensitivity. Nature 2004431 200-205. (doi:10.1038/nature02866)

33 Khamzina L, Veilleux A, Bergeron S \& Marette A. Increased activation of the mammalian target of rapamycin pathway in liver and skeletal muscle of obese rats: possible involvement in obesity-linked insulin resistance. Endocrinology 2005146 1473-1481. (doi:10.1210/en. 2004-0921)

34 Tremblay F, Brûlé S, Hee Um S, Li Y, Masuda K, Roden M, Sun XJ, Krebs M, Polakiewicz RD, Thomas $\mathrm{G}$ et al. Identification of IRS-1 Ser-1101 as a target of S6K1 in nutrient- and obesity-induced insulin resistance. PNAS 2007104 14056-14061. (doi:10.1073/pnas. 0706517104)

35 Bentzinger CF, Romanino K, Cloëtta D, Lin S, Mascarenhas JB, Oliveri F, Xia J, Casanova E, Costa CF, Brink M et al. Skeletal muscle-specific ablation of raptor, but not of rictor, causes metabolic changes and results in muscle dystrophy. Cell Metabolism 20088 411-424. (doi:10.1016/j.cmet.2008.10.002)

36 Sengupta S, Peterson TR, Laplante M, Oh S \& Sabatini DM. mTORC1 controls fasting-induced ketogenesis and its modulation by ageing. Nature 2010468 1100-1104. (doi:10.1038/nature09584)

37 Rachdi L, Balcazar N, Osorio-Duque F, Elghazi L, Weiss A, Gould A, Chang-Chen KJ, Gambello MJ \& Bernal-Mizrachi E. Disruption of Tsc2 in pancreatic $\beta$ cells induces $\beta$ cell mass expansion and improved glucose tolerance in a TORC1-dependent manner. PNAS 2008105 9250-9255. (doi:10.1073/pnas.0803047105)

38 Pende M, Kozma SC, Jaquet M, Oorschot V, Burcelin R, Le MarchandBrustel Y, Klumperman J, Thorens B \& Thomas G. Hypoinsulinaemia, glucose intolerance and diminished $\beta$-cell size in S6K1-deficient mice. Nature 2000408 994-997. (doi:10.1038/35050135)

39 Shigeyama Y, Kobayashi T, Kido Y, Hashimoto N, Asahara S, Matsuda T, Takeda A, Inoue T, Shibutani Y, Koyanagi M et al. Biphasic response of pancreatic $\beta$-cell mass to ablation of tuberous sclerosis complex 2 in 
mice. Molecular and Cellular Biology 200828 2971-2979. (doi:10.1128/ MCB.01695-07)

40 Kasiske BL, de Mattos A, Flechner SM, Gallon L, Meier-Kriesche HU, Weir MR \& Wilkinson A. Mammalian target of rapamycin inhibitor dyslipidemia in kidney transplant recipients. American Journal of Transplantation 20088 1384-1392. (doi:10.1111/j.1600-6143.2008. 02272.x)

41 Blum C. Effects of sirolimus on lipids in renal allograft recipients: an analysis using the Framingham risk model. American Journal of Transplantation 20022 551-559. (doi:10.1034/j.1600-6143.2002. 20610.x)

42 Vitko S, Wlodarczyk Z, Kyllönen L, Czajkowski Z, Margreiter R, Backman L, Perner F, Rigotti P, Jaques B, Abramowicz D et al. Tacrolimus combined with two different dosages of sirolimus in kidney transplantation: results of a multicenter study. American Journal of Transplantation 20066 531-538. (doi:10.1111/j.1600-6143.2005. 01193.x)

43 Spinelli GA, Felipe CR, Park SI, Mandia-Sampaio EL, Tedesco-Silva H \& Medina-Pestana JO. Lipid profile changes during the first year after kidney transplantation: risk factors and influence of the immunosuppressive drug regimen. Transplantation Proceedings 201143 3730-3737. (doi:10.1016/j.transproceed.2011.08.074)

44 Baur B, Oroszlan M, Hess O, Carrel T \& Mohacsi P. Efficacy and safety of sirolimus and everolimus in heart transplant patients: a retrospective analysis. Transplantation Proceedings 201143 1853-1861. (doi:10.1016/ j.transproceed.2011.01.174)

45 Tenderich G, Fuchs U, Zittermann A, Muckelbauer R, Berthold HK \& Koerfer R. Comparison of sirolimus and everolimus in their effects on blood lipid profiles and haematological parameters in heart transplant recipients. Clinical Transplantation 200721 536-543. (doi:10.1111/ j.1399-0012.2007.00686.x)

46 Gonwa T, Mendez R, Yang HC, Weinstein S, Jensik S, Steinberg S \& Prograf Study Group . Randomized trial of tacrolimus in combination with sirolimus or mycophenolate mofetil in kidney transplantation: results at 6 months. Transplantation 200375 1213-1220. (doi:10.1097/ 01.TP.0000062837.99400.60)

47 Morrisett JD, Abdel-Fattah G, Hoogeveen R, Mitchell E, Ballantyne CM, Pownall HJ, Opekun AR, Jaffe JS, Oppermann S \& Kahan BD. Effects of sirolimus on plasma lipids, lipoprotein levels, and fatty acid metabolism in renal transplant patients. Journal of Lipid Research 2002 43 1170-1180. (doi:10.1194/jlr.M100392-JLR200)

48 Murgia MG, Jordan S \& Kahan BD. The side effect profile of sirolimus: a phase I study in quiescent cyclosporine-prednisone-treated renal transplant patients. Kidney International 199649 209-216. (doi:10.1038/ki.1996.28)

49 Kahan BD \& Camardo JS. Rapamycin: clinical results and future opportunities. Transplantation 200172 1181-1193. (doi:10.1097/ 00007890-200110150-00001)

50 Brattström C, Wilczek H, Tydén G, Böttiger Y, Säwe J \& Groth CG. Hyperlipidemia in renal transplant recipients treated with sirolimus (rapamycin). Transplantation 199865 1272-1274. (doi:10.1097/ 00007890-199805150-00023)

51 Lorber MI, Mulgaonkar S, Butt KM, Elkhammas E, Mendez R, Rajagopalan PR, Kahan B, Sollinger H, Li Y, Cretin N et al. Everolimus versus mycophenolate mofetil in the prevention of rejection in de novo renal transplant recipients: a 3-year randomized, multicenter, phase III study. Transplantation 200580 244-252. (doi:10.1097/01.TP. $0000164352.65613 .24)$

52 Vítko S, Margreiter R, Weimar W, Dantal J, Viljoen HG, Li Y, Jappe A, Cretin N \& RAD B201 Study Group. Everolimus (Certican) 12-month safety and efficacy versus mycophenolate mofetil in de novo renal transplant recipients. Transplantation 200478 1532-1540. (doi:10.1097/01.TP.0000141094.34903.54)

53 Wolff AC, Lazar AA, Bondarenko I, Garin AM, Brincat S, Chow L, Sun Y, Neskovic-Konstantinovic Z, Guimaraes RC, Fumoleau P et al. Randomized phase III placebo-controlled trial of letrozole plus oral temsirolimus as first-line endocrine therapy in postmenopausal women with locally advanced or metastatic breast cancer. Journal of Clinical Oncology 201331 195-202. (doi:10.1200/JCO.2011.38.3331)

54 Busaidy NL, Farooki A, Dowlati A, Perentesis JP, Dancey JE, Doyle LA, Brell JM \& Siu LL. Management of metabolic effects associated with anticancer agents targeting the PI3K-Akt-mTOR pathway. Journal of Clinical Oncology 201230 2919-2928. (doi:10.1200/JCO.2011.39.7356)

55 Sipula IJ, Brown NF \& Perdomo G. Rapamycin-mediated inhibition of mammalian target of rapamycin in skeletal muscle cells reduces glucose utilization and increases fatty acid oxidation. Metabolism $2006 \mathbf{5 5}$ 1637-1644. (doi:10.1016/j.metabol.2006.08.002)

56 Hoogeveen RC, Ballantyne CM, Pownall HJ, Opekun AR, Hachey DL, Jaffe JS, Oppermann S, Kahan BD \& Morrisett JD. Effect of sirolimus on the metabolism of apoB100-containing lipoproteins in renal transplant patients. Transplantation 200172 1244-1250. (doi:10.1097/00007890200110150-00011)

57 Kraemer FB, Takeda D, Natu V \& Sztalryd C. Insulin regulates lipoprotein lipase activity in rat adipose cells via wortmannin- and rapamycin-sensitive pathways. Metabolism 199847 555-559. (doi:10.1016/S0026-0495(98)90239-6)

58 Ma KL, Ruan XZ, Powis SH, Chen Y, Moorhead JF \& Varghese Z. Sirolimus modifies cholesterol homeostasis in hepatic cells: a potential molecular mechanism for sirolimus-associated dyslipidemia. Transplantation 200784 1029-1036. (doi:10.1097/01.tp.0000286095. 55685.e9)

59 Costet P, Krempf M \& Cariou B. PCSK9 and LDL cholesterol: unravelling the target to design the bullet. Trends in Biochemical Sciences 200833 426-434. (doi:10.1016/j.tibs.2008.06.005)

60 Ai D, Chen C, Han S, Ganda A, Murphy AJ, Haeusler R, Thorp E, Accili D, Horton JD \& Tall AR. Regulation of hepatic LDL receptors by mTORC1 and PCSK9 in mice. Journal of Clinical Investigation 2012122 1262-1270. (doi:10.1172/JCI61919)

61 Stallone G, Infante B, Grandaliano G \& Gesualdo L. Management of side effects of sirolimus therapy. Transplantation 200987 (8 Suppl) S23-S26. (doi:10.1097/TP.0b013e3181a05b7a)

62 Johnston O, Rose CL, Webster AC \& Gill JS. Sirolimus is associated with new-onset diabetes in kidney transplant recipients. Journal of the American Society of Nephrology 200819 1411-1418. (doi:10.1681/ ASN.2007111202)

63 Teutonico A, Schena PF \& Di Paolo S. Glucose metabolism in renal transplant recipients: effect of calcineurin inhibitor withdrawal and conversion to sirolimus. Journal of the American Society of Nephrology 200516 3128-3135. (doi:10.1681/ASN.2005050487)

64 Pavel ME, Hainsworth JD, Baudin E, Peeters M, Hörsch D, Winkler RE Klimovsky J, Lebwohl D, Jehl V, Wolin EM et al. Everolimus plus octreotide long-acting repeatable for the treatment of advanced neuroendocrine tumours associated with carcinoid syndrome (RADIANT-2): a randomised, placebo-controlled, phase 3 study. Lancet 2011378 2005-2012. (doi:10.1016/S0140-6736(11)61742-X)

65 Fang Y, Westbrook R, Hill C, Boparai RK, Arum O, Spong A, Wang F, Javors MA, Chen J, Sun LY et al. Duration of rapamycin treatment has differential effects on metabolism in mice. Cell Metabolism $2013 \mathbf{1 7}$ 456-462. (doi:10.1016/j.cmet.2013.02.008)

66 Fraenkel M, Ketzinel-Gilad M, Ariav Y, Pappo O, Karaca M, Castel J, Berthault MF, Magnan C, Cerasi E, Kaiser N et al. mTOR inhibition by rapamycin prevents $\beta$-cell adaptation to hyperglycemia and exacerbates the metabolic state in type 2 diabetes. Diabetes 200857 945-957. (doi:10.2337/db07-0922)

67 Houde VP, Brûlé S, Festuccia WT, Blanchard P-G, Bellmann K, Deshaies Y \& Marette A. Chronic rapamycin treatment causes glucose intolerance and hyperlipidemia by upregulating hepatic gluconeogenesis and impairing lipid deposition in adipose tissue. Diabetes 2010 59 1338-1348. (doi:10.2337/db09-1324)

68 Lamming DW, Ye L, Katajisto P, Goncalves MD, Saitoh M, Stevens DM, Davis JG, Salmon AB, Richardson A, Ahima RS et al. Rapamycininduced insulin resistance is mediated by mTORC2 loss and uncoupled 
from longevity. Science 2012335 1638-1643. (doi:10.1126/science. 1215135)

69 Chresta CM, Davies BR, Hickson I, Harding T, Cosulich S, Critchlow SE, Vincent JP, Ellston R, Jones D, Sini P et al. AZD8055 is a potent, selective, and orally bioavailable ATP-competitive mammalian target of rapamycin kinase inhibitor with in vitro and in vivo antitumor activity. Cancer Research 201070 288-298. (doi:10.1158/0008-5472. CAN-09-1751)

70 Di Paolo S, Teutonico A, Leogrande D, Capobianco C \& Schena PF. Chronic inhibition of mammalian target of rapamycin signaling downregulates insulin receptor substrates 1 and 2 and AKT activation: a crossroad between cancer and diabetes? Journal of the American Society of Nephrology 200617 2236-2244. (doi:10.1681/ASN.2006030196)

71 Pereira MJ, Palming J, Rizell M, Aureliano M, Carvalho E, Svensson MK \& Eriksson JW. mTOR inhibition with rapamycin causes impaired insulin signalling and glucose uptake in human subcutaneous and omental adipocytes. Molecular and Cellular Endocrinology 2012355 96-105. (doi:10.1016/j.mce.2012.01.024)

72 Kulke MH, Bergsland EK \& Yao JC. Glycemic control in patients with insulinoma treated with everolimus. New England Journal of Medicine 2009360 195-197. (doi:10.1056/NEJMc0806740)

73 Bernard V, Lombard-Bohas C, Taquet MC, Caroli-Bosc FX, Ruszniewski P, Niccoli P, Guimbaud R, Chougnet CN, Goichot B, Rohmer $\mathrm{V}$ et al. Efficacy of everolimus in patients with metastatic insulinoma and refractory hypoglycemia. European Journal of Endocrinology 2013168 665-674. (doi:10.1530/EJE-12-1101)

74 Gottardi M, Manzato E \& Gherlinzoni F. Imatinib and hyperlipidemia. New England Journal of Medicine 2005353 2722-2723. (doi:10.1056) NEJMc052500)

75 Lodish MB \& Stratakis CA. Endocrine side effects of broad-acting kinase inhibitors. Endocrine-Related Cancer 201017 R233-R244. (doi:10.1677/ ERC-10-0082)

76 Veneri D, Franchini $\mathrm{M} \&$ Bonora E. Imatinib and regression of type 2 diabetes. New England Journal of Medicine 2005352 1049-1050. (doi:10.1056/NEJM200503103521023)
77 Breccia M, Muscaritoli M, Aversa Z, Mandelli F \& Alimena G. Imatinib mesylate may improve fasting blood glucose in diabetic $\mathrm{Ph}+$ chronic myelogenous leukemia patients responsive to treatment. Journal of Clinical Oncology 200422 4653-4655. (doi:10.1200/JCO.2004.04.217)

78 Hamberg P, de Jong FA, Boonstra JG, van Doorn J, Verweij J \& Sleijfer S. Non-islet-cell tumor induced hypoglycemia in patients with advanced gastrointestinal stromal tumor possibly worsened by imatinib. Journal of Clinical Oncology 200624 e30-e31. (doi:10.1200/JCO.2006. 06.5318)

79 Billemont B, Medioni J, Taillade L, Helley D, Meric JB, Rixe O \& Oudard S. Blood glucose levels in patients with metastatic renal cell carcinoma treated with sunitinib. British Journal of Cancer 200899 1380-1382. (doi:10.1038/sj.bjc.6604709)

80 Oh JJ, Hong SK, Joo YM, Lee BK, Min SH, Lee S, Byun SS \& Lee SE. Impact of sunitinib treatment on blood glucose levels in patients with metastatic renal cell carcinoma. Japanese Journal of Clinical Oncology 201242 314-317. (doi:10.1093/jjco/hys002)

81 Aichberger KJ, Herndlhofer S, Schernthaner GH, Schillinger M, Mitterbauer-Hohendanner G, Sillaber C \& Valent P. Progressive peripheral arterial occlusive disease and other vascular events during nilotinib therapy in CML. American Journal of Hematology 201186 533-539. (doi:10.1002/ajh.22037)

82 Valent P. Severe adverse events associated with the use of second-line BCR/ABL tyrosine kinase inhibitors: preferential occurrence in patients with comorbidities. Haematologica 201196 1395-1397. (doi:10.3324/ haematol.2011.052076)

83 Lombard-Bohas C, Cariou B, Vergès B, Coriat R, N'Guyen T, François E, Hammel P, Niccoli P \& Hentic O. Management of metabolic disorders induced by everolimus in patients with differentiated neuroendocrine tumors: expert proposals. Bulletin du Cancer 2013. In press.

84 Reichardt P, Blay JY, Gelderblom H, Schlemmer M, Demetri GD, Bui-Nguyen B, McArthur GA, Yazji S, Hsu Y, Galetic I et al. Phase III study of nilotinib versus best supportive care with or without a TKI in patients with gastrointestinal stromal tumors resistant to or intolerant of imatinib and sunitinib. Annals of Oncology 201223 1680-1687. (doi:10.1093/annonc/mdr598)

Received 17 July 2013

Revised version received 9 October 2013

Accepted 23 October 2013 